\title{
Chorein Sensitive Arrangement of Cytoskeletal Architecture
}

\author{
Sabina Honisch ${ }^{a}$ Shuchen Gu ${ }^{a, b}$ Jennifer Müller vom Hagen ${ }^{c, g}$ Saad Alkahtanid,e \\ Abdullah A. Al Kahtane ${ }^{d}$ Anna Tsapara ${ }^{e}$ Andreas Hermann ${ }^{f}$ Alexander Storch $^{f}$ \\ Ludger Schöls ${ }^{c, g}$ Florian Langa Christos Stournaras ${ }^{a, d, e}$ \\ aDepartment of Physiology, University of Tübingen, Tübingen, Germany; 'bife Sciences Institute, \\ Zhejiang University, Hangzhou, Zhejiang, China; 'Department of Neurology and Hertie-Institute \\ for Clinical Brain Research, University of Tübingen, Tübingen, Germany; dDepartment of Zoology, \\ Science College, King Saud University, Riyadh, Saudi Arabia; 'Department of Biochemistry, University \\ of Crete Medical School, Heraklion, Greece; 'Division for Neurodegenerative Diseases, Department \\ of Neurology, Technische Universität Dresden, Germany and German Centre for Neurodegenerative \\ Diseases (DZNE) Dresden, Dresden, Germany; ${ }^{9}$ German Center of Neurodegenerative Diseases (DZNE), \\ Tübingen, Germany
}

\section{Key Words}

Chorein • Fibroblasts • Actin • Tubulin • Desmin • Cytokeratins

\begin{abstract}
Background/Aims: Chorein is a protein expressed in various cell types. Loss of function mutations of the chorein encoding gene VPS13A lead to chorea-acanthocytosis, an autosomal recessive genetic disease characterized by movement disorder and behavioral abnormalities. Recent observations revealed that chorein is a powerful regulator of actin cytoskeleton in erythrocytes, platelets, K562 and endothelial HUVEC cells. Methods: In the present study we have used Western blotting to study actin polymerization dynamics, laser scanning microscopy to evaluate in detail the role of chorein in microfilaments, microtubules and intermediate filaments cytoskeleton architecture and RT-PCR to assess gene transcription of the cytoskeletal proteins. Results: We report here powerful depolymerization of actin microfilaments both, in erythrocytes and fibroblasts isolated from chorea-acanthocytosis patients. Along those lines, morphological analysis of fibroblasts from chorea-acanthocytosis patients showed disarranged microtubular network, when compared to fibroblasts from healthy donors. Similarly, the intermediate filament networks of desmin and cytokeratins showed significantly disordered organization with clearly diminished staining in patient's fibroblasts. In line with this, RT-PCR analysis revealed significant downregulation of desmin and cytokeratin gene transcripts. Conclusion: Our results provide for the first time evidence that defective chorein is accompanied by significant structural disorganization of all cytoskeletal structures in human fibroblasts from chorea-acanthocytosis patients.

S. Honisch and S. Gu contributed equally thus sharing first authorship. F. Lang and C. Stournaras contributed equally thus sharing last authorship. 


\section{Introduction}

Chorein is expressed in a wide variety of cells [1-5]. The protein is encoded by the VPS13A (vacuolar protein sorting 13 homolog A) gene [6]. Loss of function mutations [4] of VPS13A [7-10] lead to chorea-acanthocytosis (ChAc), an autosomal recessive genetic disease characterized by movement disorder and behavioral abnormalities $[4,7,11]$. The disease becomes apparent in adulthood and slowly progresses eventually leading to severe neuromuscular dysfunction with several clinical features, such as tongue- and lip-biting, self-mutilations, and seizures [12-15].

In erythrocytes from ChAc patients the lack of chorein leads to almost complete disappearance of the cortical actin filaments network and thus to the spectacular erythrocyte shape change of acanthocytosis [1, 16]. Chorein is further expressed in K562 cells [1], blood platelets [17], human umbilical vein endothelial cells (HUVECs) [18] and some tumor cells [5]. Down-regulation of chorein expression was shown to drastically modify actin cytoskeleton architecture and polymerization dynamics in those cells [1]. In addition, chorein silencing inhibited specific actin signaling regulators, including Rac1 GTPase and PAK1 [1]. Moreover, proteomic analysis of erythrocytes membranes from ChAc-patients revealed markedly decreased beta-actin protein levels, while co-IP assays showed interactions of chorein with beta-actin [19]. These observations established a crucial role of chorein in actin cytoskeleton organization and function. However, the possible impact of this protein on the integrity of the additional cytoskeletal structures, including microtubules and intermediate filaments has not been addressed so far.

Organization of cytoskeletal structures is crucial for cellular physiology and function [20-23]. Impaired cytoskeletal dynamics and disarranged structural organization underlie several human diseases, including muscular dystrophy [24-26], cardiac disorders [27], liver diseases [28] and malignancies [29-32]. Since ChAc is a genetic disease affecting multiple organs including brain and blood, but also muscle and liver cells [4, 7], disarranged cytoskeletal structures may not be limited to actin microfilaments. In the present study we thus explored the impact of chorein on the structural profile of actin microfilaments, microtubules, and intermediate filaments. The analysis was performed in cells isolated from chorea-acanthocytosis patients expressing defective chorein levels. The cell types chosen were erythrocytes, which are known to virtually lack cortical actin and are highly deformed $[1,16]$, and fibroblasts, which could be cultured ex vivo following isolation from patients and healthy volunteers and are considered a particularly appropriate cell type for the detailed study of cytoskeletal reorganization and signaling [33-35]. Our findings provide evidence that chorein deficiency influences the organization of all three cytoskeletal structures, implying a role of this protein in the maintenance of cytoskeleton integrity.

\section{Materials and Methods}

\section{Human erythrocytes and fibroblasts}

Blood from patients and healthy volunteers was used. The volunteers providing erythrocytes gave informed consent. The study has been approved by the Ethical Commission of the University of Tübingen and Dresden (EK45022009). Fibroblast from patients (n=9) and healthy volunteers (n=9) were isolated from human skin biopsy after receiving the approval of the Hospital Ethics Committee. Skin biopsies were minced using sterile techniques and washed twice in phosphate buffered saline (PBS) supplemented with antibiotics (100 U/ml penicillin and $100 \mathrm{mg} / \mathrm{ml}$ streptomycin). Explants were placed into $25 \mathrm{~cm}^{2}$ flasks and maintained in Dulbecco's modified Eagle's medium (DMEM) supplemented with $10 \%$ fetal calf serum (FCS) and antibiotics, as described above. Cultures were maintained at $37^{\circ} \mathrm{C}$ in a humidified atmosphere of $5 \% \mathrm{CO}_{2}$ and $95 \%$ air. Once the fibroblasts were established, the fungizone was omitted from the medium. Confluent cells were detached by treatment with $0.25 \%$ trypsin and $0.05 \%$ EDTA for $5 \mathrm{~min}$, and aliquots of separated cells were subcultured with the same medium. Cell cultures between the third and eighth passages were used in this study. 


\section{Confocal laser scanning microscopy}

Erythrocytes from healthy volunteers or patients with chorea-acanthocytosis were suspended in PBS at a cell density of $5 \times 10^{7}$ cells $/ \mathrm{ml}$. Ten $\mu \mathrm{l}$ of the suspension were smeared onto a glass slide that was air dried for $30 \mathrm{~min}$ and then fixed with methanol for $2 \mathrm{~min}$. After four washing steps with PBS for $10 \mathrm{~min}$., the specimen was used for actin staining. Fibroblasts from healthy volunteers or patients with choreaacanthocytosis were grown in 24 well plates with a coverslip inside. To determine $\alpha$-tubulin, desmin, and cytokeratins, cells were fixed with 4\% PFA for $15 \mathrm{~min}$ at room temperature. After washing twice with PBS the slides were incubated with $5 \%$ normal goat serum $/ 1 \times \mathrm{PBS} / 0.3 \%$ Triton for $1 \mathrm{~h}$ at room temperature. Then, the specimens were exposed overnight at $4^{\circ} \mathrm{C}$ to $\alpha$-tubulin (1:50; Cell Signaling), desmin (1:100, Santa Cruz Biotechnology) or pan-cytokeratin (1:100, Santa Cruz Biotechnology) antibodies. The slides were rinsed three times with PBS and incubated for $1.5 \mathrm{~h}$ at room temperature with secondary FITC goat anti-rabbit antibody (1:500; Invitrogen). After three washing steps the nuclei were stained for $10 \mathrm{~min}$ at room temperature with DRAQ-5 dye (1:1000; Biostatus). Slides were mounted using the ProLang® Gold Antifade reagent (Invitrogen). Confocal microscopy was performed with a Zeiss LSM 5 EXCITER confocal laser-scanning module (Carl Zeiss) and images were analyzed with the software of the instrument.

\section{Measurement of the G/total actin ratio by Triton X-100 fractionation}

The Triton X-100 soluble erythrocyte or fibroblast fractions containing G-actin and F-actin were prepared as previously described [36]. In brief, samples were incubated in $50 \mathrm{ml}$ of Triton-extraction buffer consisting of 0.3\% Triton X-100, $5 \mathrm{mM}$ Tris, pH 7.4, 2 mM EGTA, $300 \mathrm{mM}$ sucrose, $2 \mathrm{mM}$ phalloidin, $1 \mathrm{mM}$ PMSF, $10 \mathrm{mg} / \mathrm{ml}$ leupeptin, $20 \mathrm{mg} / \mathrm{ml}$ aprotinin, $1 \mathrm{mM}$ sodium orthovanadate, and $50 \mathrm{mM} \mathrm{NaF}$ for $5 \mathrm{~min}$ on ice. The supernatant containing the soluble proteins was removed by aspiration. The Triton-insoluble pellet was scraped from the plate directly into $50 \mathrm{ml}$ of RIPA buffer consisting of $50 \mathrm{mM}$ Tris/HCl, $\mathrm{pH} 7.4,1 \%$ Triton X-100, 1\% sodium deoxycholate, $0.1 \%$ SDS, $0.15 \mathrm{M} \mathrm{NaCl}, 1 \mathrm{mM}$ EDTA, $1 \mathrm{mM}$ DTT, and $1 \mathrm{mM}$ sodium orthovanadate. Any remaining insoluble material was removed by centrifugation. Equal volumes of each fraction were subjected to SDS-PAGE and Western blotting using monoclonal anti-actin antibodies ( Cell Signaling). An increase of the ratio of Tritonsoluble G-actin to insoluble F-actin was considered as an indicator of actin depolymerization.

\section{Quantitative real-time PCR}

To demonstrate the transcript levels of tubulin, desmin and keratin10 total RNA was isolated from fibroblasts of healthy individuals and ChAc patients using the Trifast Reagent (Peqlab, Erlangen, Germany). Two $\mu$ g RNA from each sample were reverse-transcribed using oligo(dT)12-18 primers and GoScript Reverse Transcriptase Kit (Promega) according to the manufacturer's protocol. Quantitative real-time PCR was performed with the BioRad iCycler iQTM Real-Time PCR Detection System (Bio-Rad Laboratories) using GoTaq Sybr Green Master Mix (Promega). The reaction was under following conditions: an initial incubation at $95^{\circ} \mathrm{C}$ for $5 \mathrm{~min}, 40 \mathrm{cycles}$ at $95^{\circ} \mathrm{C}$ for $15 \mathrm{~s}, 59^{\circ} \mathrm{C}$ for $20 \mathrm{~s}$ and $72^{\circ} \mathrm{C}$ for $30 \mathrm{~s}$. Specificity of the PCR products was verified by melting curve analysis. The subsequent primers were used ( $5^{\prime} \rightarrow 3^{\prime}$ orientation):

Desmin fw: AGGACCTGCTCAACGTGAAG

Desmin rev: TCGATGGTCTTGATCATCACC

Keratin10 fw: AGATGCTGAAGCCTGGTTCAATG

Keratin 10 rev: TGAGCAGAGTCTTCAGAGACAGC

Tubulin1 alpha fw: TGTAGACTTGGAACCCACAGTC

Tubulin1 alpha rev: AACCAAGAAGCCCTGGAGAC

Tubulin beta fw: TCAGTGTGGCAACCAGATCG

Tubulin beta rev: TAGATCCACCAGGATGGCAC

GAPDH fw: TGAGTACGTCGTGGAGTCCACTG

GAPDH rev: GGTGCTAAGCAGTTGGTGGTG

The transcript levels were calculated according to the $\Delta \Delta \mathrm{Ct}$ method and normalized to the expression levels of GAPDH in the same cDNA sample.

\section{Statistical analysis}

Data are expressed as arithmetic means \pm SD or \pm SEM as indicated and statistical analysis was made by unpaired t-test. $\mathrm{p}<0.05$ was considered as statistically significant.

\section{KARGER}


Fig. 1. Actin microfilament staining in erythrocytes from ChAc-patients and healthy donors. Confocal micrographs of actin staining in erythrocytes from healthy individuals (left) or from patients with ChAc (right). Rhodamine-phalloidin was used for filamentous actin staining. Bar represents $5 \mu \mathrm{m}$.

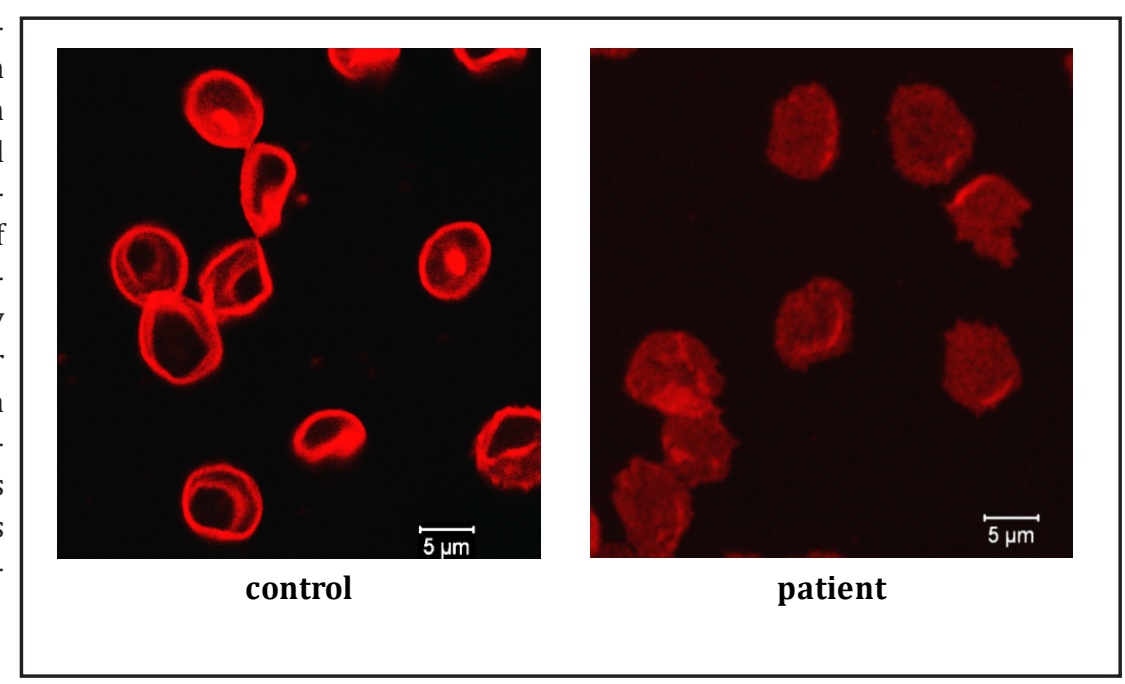

\section{Results}

Previous observations in human erythrocytes isolated from ChAc-patients [1] revealed clear decrease in F-actin content and increase in G/F-actin ratio in ChAc-patients samples compared to erythrocytes isolated from healthy donors. In line with these reports, microscopic analysis of erythrocytes from ChAc-patients revealed significantly disarranged actin microfilament organization when compared with healthy donors (Fig. 1).

Quantification of the actin polymerization equilibrium by Western blotting showed clear decrease in F-actin content and increase in G/F-actin ratio (data not shown). These findings fully corroborate the previous observations [1].

Based on these control experiments we further addressed whether actin microfilament network is similarly disarranged in fibroblasts from the ChAc-patients. Figure 2A shows representative micrographs from confocal laser scanning microscopy assessment of fibroblasts isolated from patients $(n=5)$ and healthy donors $(n=5)$, revealing clearly diminished actin microfilament staining in patient's fibroblasts as compared to fibroblasts from healthy donors (Fig. 2A). This finding was fully supported by western blotting showing substantial increase in monomeric G-actin and decrease in filamentous F-actin content (Fig. 2B) and hence a significant increase in the G-/F-actin ratio (Fig. 2C), implying clear actin cytoskeleton reorganization in fibroblasts isolated from ChAc-patients.

Having established the actin cytoskeleton disarrangement in fibroblasts from ChAcpatients, we further evaluated the morphology patterns of the other classes of cytoskeletal structures. As compared to fibroblasts isolated from healthy donors (Fig. 3 upper panels), in fibroblasts from ChAc-patients staining of microtubular network was diminished with punctuated staining pointing to tubulin depolymerisation and less microtubules (Fig. 3 lower panels). Interestingly, PCR analysis revealed similar tubulin gene transcripts in fibroblasts from ChAc-patients and healthy donors (data not shown), implying unchanged tubulin expression. This finding is in line with previous reported results in K652 cells [1].

Further morphological evaluation of intermediate filament structures in fibroblasts from ChAc-patients revealed different filamentous patterns for desmin- (Fig. 4A) and cytokeratins- (Fig. 5A) intermediate filament networks. For both structural proteins, staining seems to be diminished in fibroblasts from ChAc-patients when compared to control cells, while doted staining is visualized, pointing to reduced expression of these proteins in ChAc-patients. This assumption is fully supported by RT-PCR analysis, showing significant decrease of gene transcription for both desmin (Fig. 4B) and cytokeratin-10 (Fig. 5B) in ChAc-patients compared to healthy donors. Although quantitative estimates of monomer/polymer equilibrium remain to be established, the morphological evaluation

\section{KARGER}


Fig. 2. Actin microfilament staining and G-/F-actin dynamics in fibroblasts from ChAc-patients and healthy donors. (A) Confocal micrographs of actin staining in fibroblasts from healthy individuals (left) or from patients with ChAc (right). DRAQ5 ${ }^{\mathrm{Tm}}$ was used for nuclei staining and rhodamine-phalloidin for filamentous actin staining. Bar: $20 \mu \mathrm{m}$. B. Original Western blots demonstrating filamentous (F) and soluble (G) actin content in fibroblasts from healthy individuals (left) or from patients with ChAc (right). (C) Arithmetic mean \pm SD $(n=3)$ of the ratio of soluble (G) actin and filamentous (F) actin in fibroblasts from healthy individuals (control) or from patients with ChAc (patient). ${ }^{* *}$ indicates $\mathrm{p}<0.01$.

Fig. 3. Microtubules staining in fibroblasts from ChAcpatients and healthy donors. Confocal micrographs of microtubules staining in fibroblasts from healthy individuals (upper) or from patients with ChAc (lower) panels. DRAQ5 $^{\mathrm{TM}}$ was used for nuclei staining and anti-tubulin FITC-conjugated antibody for microtubules staining. Bar: 10 $\mu \mathrm{m}$.
A
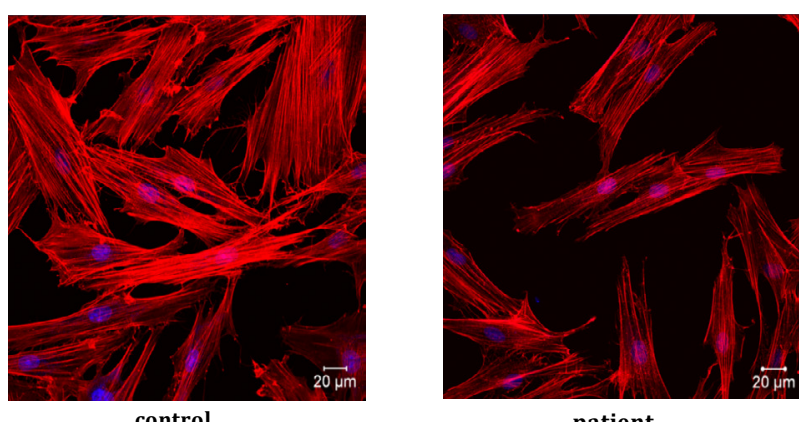

patient

B

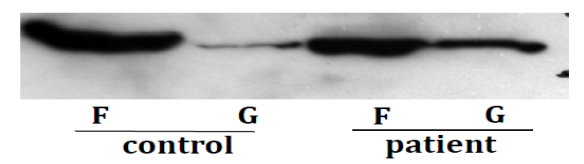

C

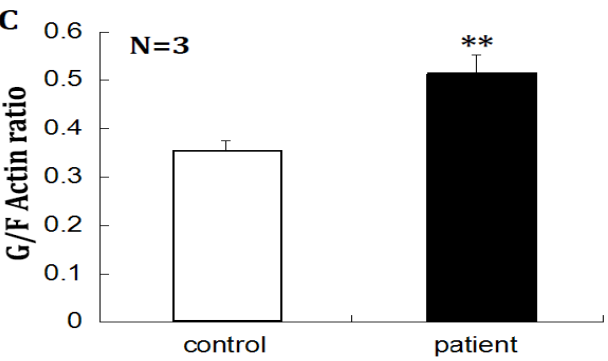

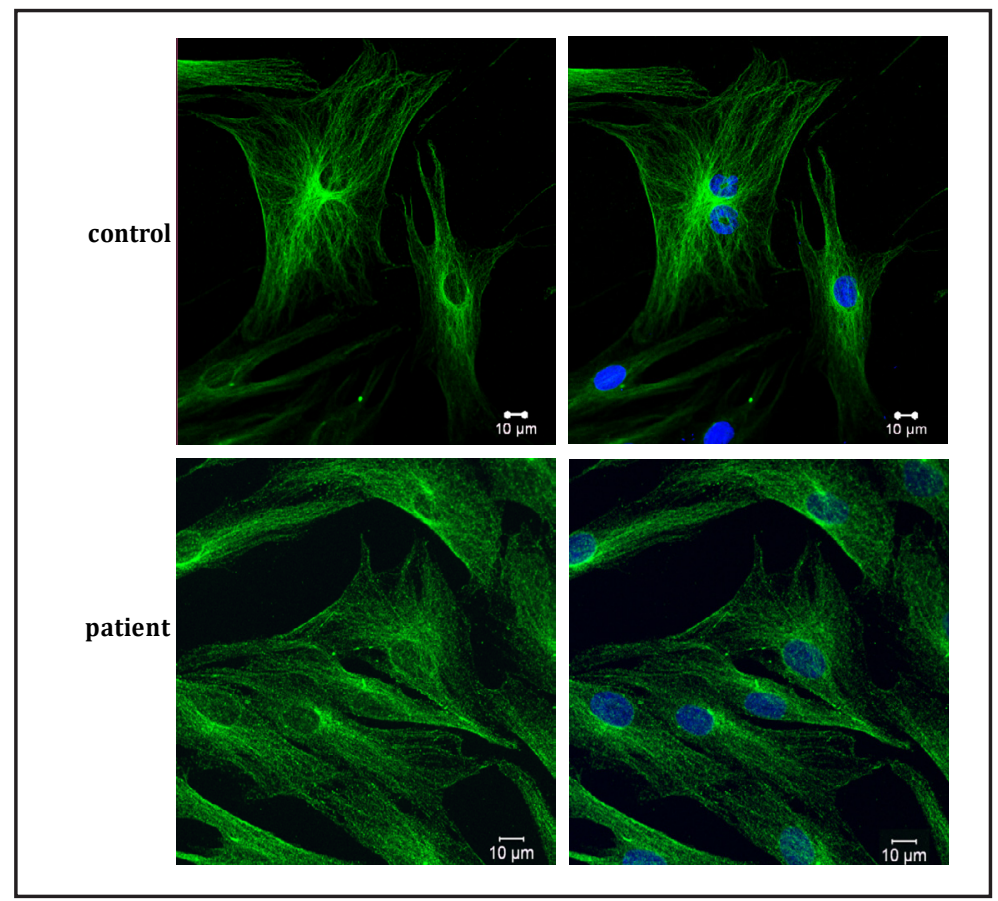

and PCR analysis points to possible disorganization of intermediate filament structures in fibroblasts isolated from chorein deficient ChAc-patients. 
A

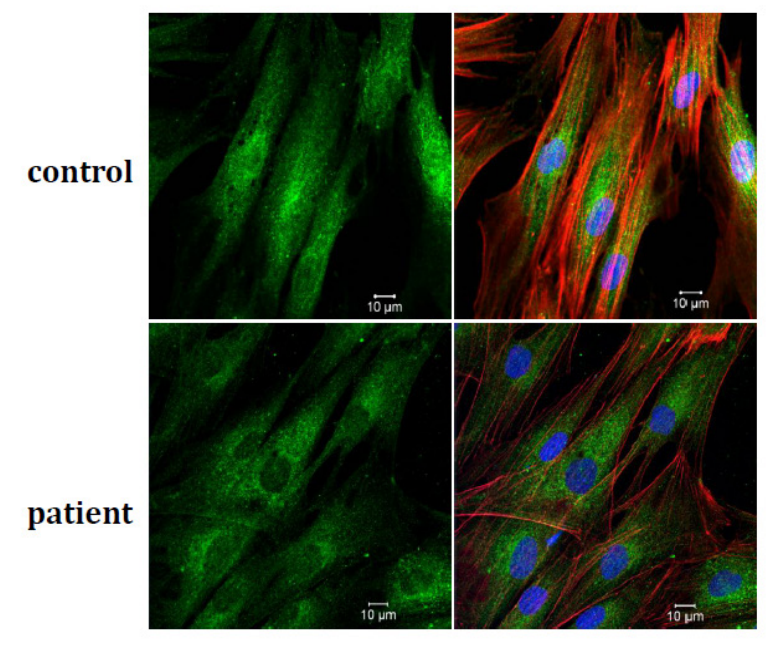

B

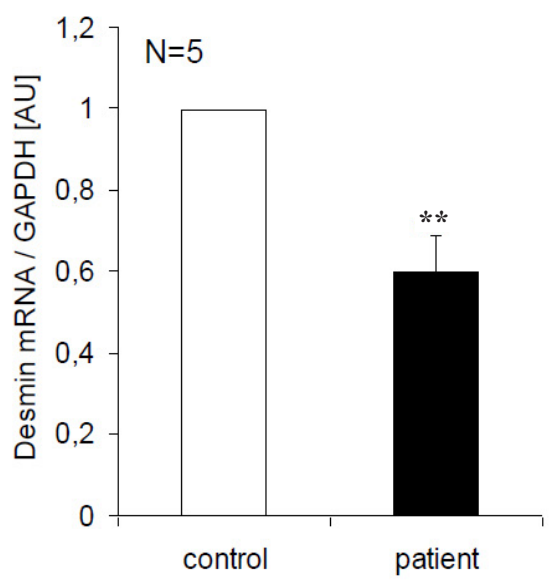

Fig. 4. Desmin intermediate filaments in fibroblasts from ChAc-patients and healthy donors. (A) Confocal micrographs of desmin intermediate filaments staining in fibroblasts from healthy individuals (upper pannels) or from patients with ChAc (lower panels). DRAQ5 ${ }^{\mathrm{TM}}$ was used for nuclei staining, anti-desmin FITCconjugated antibody for desmin staining and rhodamine-phalloidin for filamentous actin staining. Bar: 10 $\mu \mathrm{m}$. (B) Desmin transcript levels from control and ChAc (patient) fibroblasts determined by real-time PCR. Shown are the mean values of $2^{-\Delta C t}$ using GAPDH as housekeeping gene \pm SEM from $n=5$ independent experiments. ${ }^{* *}(\mathrm{p}<0,01$; unpaired t-test) indicates a significant difference between the controls and patients.

A

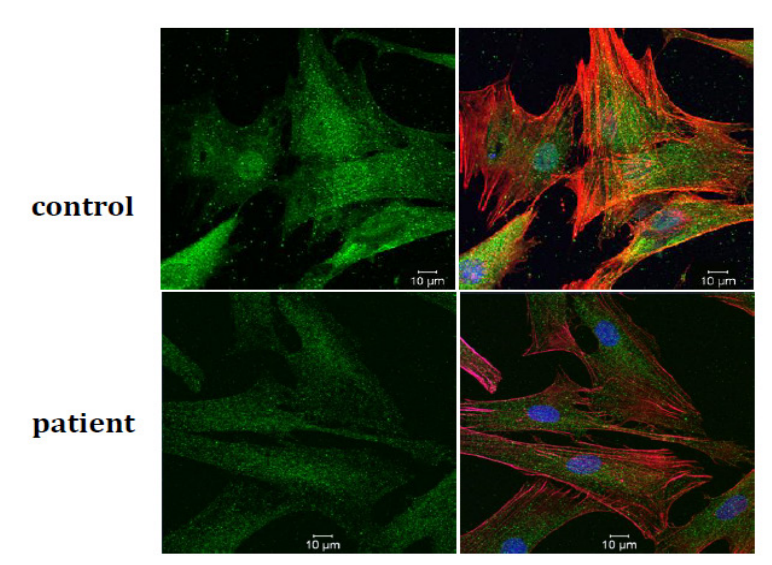

B

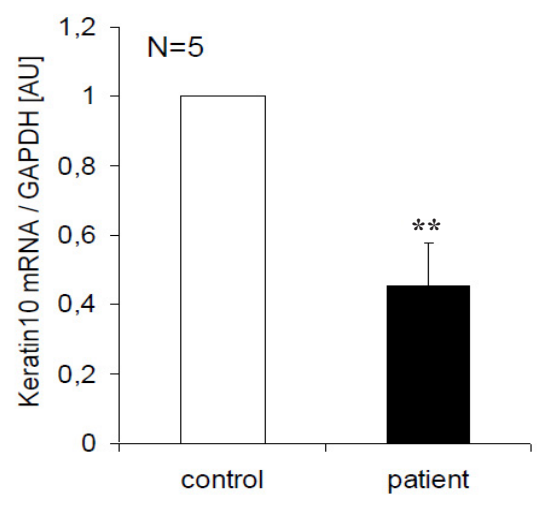

Fig. 5. Cytokeratins in fibroblasts from ChAc-patients and healthy donors. (A). Confocal micrographs of cytokeratin intermediate filaments staining in fibroblasts from healthy individuals (upper pannels) or from patients with ChAc (lower panels). DRAQ5 ${ }^{\mathrm{TM}}$ was used for nuclei staining, anti-pan-cytokeratin FITC- conjugated antibody for cytokeratins staining and rhodamine-phalloidin for filamentous actin staining. Bar: 10 $\mu \mathrm{m}$. (B). Keratin10 transcript levels from control and ChAc (patient) fibroblasts determined by real-time PCR. Shown are the mean values of $2^{-\Delta C t}$ using GAPDH as housekeeping gene \pm SEM from $n=5$ independent experiments. ${ }^{* *}(\mathrm{p}<0,01$; unpaired t-test) indicates a significant difference between the controls and patients.

\section{KARGER}




\section{Discussion}

This study discloses the novel finding that cytoskeletal structures are disarranged in fibroblasts from chorein deficient ChAc-patients. As observed earlier in human erythrocytes from ChAc-patients, actin cytoskeleton organization is strongly affected by significant depolymerization of actin microfilaments. Microtubules and intermediate filament structures are as well profoundly reorganized in fibroblasts from chorein deficient ChAc-patients. Indeed, depolymerization of filamentous structures towards formation of monomeric tubulin, desmin and cytokeratins became evident in morphological analysis by laser scanning microscopy of the corresponding cytoskeletal structures.

The role of chorein in actin cytoskeleton organization and polymerization dynamics has been addressed in detail both in erythrocytes from ChAc-patients as well as in various cell models, including platelets, K562 cells and endothelial HUVEC cells [1, 17, 18, 37]. It was established that chorein deficiency, either through low expression of the protein in samples isolated from ChAc-patients, or through chorein-silencing in cell cultures, is associated with loss of microfilament structures and significant increase of monomeric G-actin expression, pointing to substantial actin depolymerization. The molecular mechanism governing this structural reorganisation revealed the implication of FAK/PI-3K signaling $[1,18]$ and the specific actin regulating molecules Rac1 GTPase and PAK1 [38]. In addition, this extensive actin reorganization was related to differential stiffness behaviour of endothelial cells upon chorein silencing [18], a finding well correlated with the significant role of diminished actin cytoskeleton stability in cellular functions [39-41], including migration [30, 42, 43], adhesion [44] and apoptosis [32, 45, 46]. Based on these reports, our finding shows depolymerised actin cytoskeleton both in erythrocytes and fibroblasts isolated from ChAc-patients implying destabilized microfilaments. Further work is now needed to establish the mechanism that underlies this actin reorganization in fibroblasts of ChAc-patients. Whether activation of the PI3K/Rac1/PAK1 pathway, particularly shown in erythrocytes [1], or the recently reported fibroblasts-specific RhoA/B /alpha-smooth-muscle-actin signaling [35, 47, 48] are involved in the regulation of microfilament reorganization in fibroblasts from ChAc-patients remains to be elucidated.

Our results based on morphological evaluation and PCR analysis of the cytoskeletal proteins further revealed reorganization of the microtubular network, as well as of the desmin- and cytokeratins-intermediate filament families in fibroblasts from ChAc-patients. These are interesting novel findings, implying that chorein deficiency is associated with disarranged intermediate filaments networks. Both, morphological evaluation and PCR gene transcription analysis support lower expression and disordered assembly of intermediate filaments. On the other hand since altered microtubular structure was not observed earlier in K562 cells [1] and in the PCR data in fibroblasts from ChAc-patients presented here, it is presently not clear whether microtubular monomer/polymer equilibrium rearrangements -rather than tubulin expression- are a fibroblast-specific effect, or may be a general chorein-dependent phenomenon, manifested as well in other cell systems. Indeed, the cellular specificity of these observations, as well as the quantitative evaluation of the morphological findings by monomer-polymer equilibrium assessment of microtubule and intermediate filament structures needs further analysis. However, since disorders in cytoskeletal structures assembly have been described to be implicated in various human diseases including muscular dystrophy $[20,26,28]$, our observations of chorein-sensitive disorganization of all cytoskeletal structures in fibroblasts from ChAc-patients may shed novel light on the molecular and cellular pathophysiology of this devastating neurological disease.

\section{Conclusions}

In the present study we report for the first time chorein sensitive disarrangement of several cytoskeletal structures in human fibroblasts isolated from ChAc-patients. These 
involve diminished filamentous networks of actin microfilaments, reduced desmin and cytokeratins gene expression, as well as rearrangements in microtubules, desmin- and cytokeratin-intermediate filaments staining. Further studies are now needed to establish whether the chorein sensitivity of cytoskeletal organization may be correlated with the neuropathophysiological behaviour of AcCh-patients.

\section{Acknowledgements}

Authors thank Tanja Loch for the meticulous preparation of this manuscript. This work was supported by grants from the Deutsche Forschungsgemeinschaft (Mercator program) and Open Access Publishing Fund of Tuebingen University; the University of Crete Research Committee (KA 3452), and the Deanship of Scientific Research at King Saud University (KSU-RGP-018 Programs). This work was in part supported by the Advocacy for Neuroacanthocytosis patients (to A.H. and A.S.) and by the Federal Ministry of Education and Research (BMBF) under the frame of E-Rare-2, the ERA-Net for Research on Rare Diseases (to A.H.).

\section{Disclosure Statement}

The authors declare that they have no competing interests.

\section{References}

-1 Foller M, Hermann A, Gu S, Alesutan I, Qadri SM, Borst O, Schmidt EM, Schiele F, vom Hagen JM, Saft C, Schols L, Lerche H, Stournaras C, Storch A, Lang F: Chorein-sensitive polymerization of cortical actin and suicidal cell death in chorea-acanthocytosis. FASEB J 2012;26:1526-1534.

- Hayashi T, Kishida M, Nishizawa Y, Ijima M, Koriyama C, Nakamura M, Sano A, Kishida S: Subcellular localization and putative role of VPS13A/chorein in dopaminergic neuronal cells. Biochem Biophys Res Commun 2012;419:511-516.

3 Kurano Y, Nakamura M, Ichiba M, Matsuda M, Mizuno E, Kato M, Agemura A, Izumo S, Sano A: In vivo distribution and localization of chorein. Biochem Biophys Res Commun 2007;353:431-435.

4 Saiki S, Sakai K, Murata KY, Saiki M, Nakanishi M, Kitagawa Y, Kaito M, Gondo Y, Kumamoto T, Matsui M, Hattori N, Hirose G: Primary skeletal muscle involvement in chorea-acanthocytosis. Mov Disord 2007;22:848-852.

5 Honisch S, Yu W, Liu G, Alesutan I, Towhid ST, Tsapara A, Schleicher S, Handgretinger R, Stournaras C, Lang F: Chorein addiction in VPS13A overexpressing rhabdomyosarcoma cells. Oncotarget 2015;6:1030910319.

6 Velayos-Baeza A, Vettori A, Copley RR, Dobson-Stone C, Monaco AP: Analysis of the human VPS13 gene family. Genomics 2004;84:536-549.

7 Dobson-Stone C, Danek A, Rampoldi L, Hardie RJ, Chalmers RM, Wood NW, Bohlega S, Dotti MT, Federico A, Shizuka M, Tanaka M, Watanabe M, Ikeda Y, Brin M, Goldfarb LG, Karp BI, Mohiddin S, Fananapazir L, Storch A, Fryer AE, Maddison P, Sibon I, Trevisol-Bittencourt PC, Singer C, Caballero IR, Aasly JO, Schmierer K, Dengler R, Hiersemenzel LP, Zeviani M, Meiner V, Lossos A, Johnson S, Mercado FC, Sorrentino G, Dupre N, Rouleau GA, Volkmann J, Arpa J, Lees A, Geraud G, Chouinard S, Nemeth A, Monaco AP: Mutational spectrum of the CHAC gene in patients with chorea-acanthocytosis. Eur J Hum Genet 2002;10:773-781.

-8 Dobson-Stone C, Velayos-Baeza A, Filippone LA, Westbury S, Storch A, Erdmann T, Wroe SJ, Leenders KL, Lang AE, Dotti MT, Federico A, Mohiddin SA, Fananapazir L, Daniels G, Danek A, Monaco AP: Chorein detection for the diagnosis of chorea-acanthocytosis. Ann Neurol 2004;56:299-302. 
-9 Tomiyasu A, Nakamura M, Ichiba M, Ueno S, Saiki S, Morimoto M, Kobal J, Kageyama Y, Inui T, Wakabayashi K, Yamada T, Kanemori Y, Jung HH, Tanaka H, Orimo S, Afawi Z, Blatt I, Aasly J, Ujike H, Babovic-Vuksanovic D, Josephs KA, Tohge R, Rodrigues GR, Dupre N, Yamada H, Yokochi F, Kotschet K, Takei T, Rudzinska M, Szczudlik A, Penco S, Fujiwara M, Tojo K, Sano A: Novel pathogenic mutations and copy number variations in the VPS13A gene in patients with chorea-acanthocytosis. Am J Med Genet B Neuropsychiatr Genet 2011;156B:620-631.

10 Ueno S, Maruki Y, Nakamura M, Tomemori Y, Kamae K, Tanabe H, Yamashita Y, Matsuda S, Kaneko S, Sano A: The gene encoding a newly discovered protein, chorein, is mutated in chorea-acanthocytosis. Nat Genet 2001;28:121-122.

11 Neutel D, Miltenberger-Miltenyi G, Silva I, de Carvalho M: Chorea-acanthocytosis presenting as motor neuron disease. Muscle Nerve 2012;45:293-295.

12 Danek A, Jung HH, Melone MA, Rampoldi L, Broccoli V, Walker RH: Neuroacanthocytosis: new developments in a neglected group of dementing disorders. J Neurol Sci 2005;229-230:171-186.

13 Jung HH, Danek A, Walker RH: Neuroacanthocytosis syndromes. Orphanet J Rare Dis 2011;6:68.

14 Miquel M, Spampinato U, Latxague C, Aviles-Olmos I, Bader B, Bertram K, Bhatia K, Burbaud P, Burghaus L, Cho JW, Cuny E, Danek A, Foltynie T, Garcia Ruiz PJ, Gimenez-Roldan S, Guehl D, Guridi J, Hariz M, Jarman P, Kefalopoulou ZM, Limousin P, Lipsman N, Lozano AM, Moro E, Ngy D, Rodriguez-Oroz MC, Shang H, Shin H, Walker RH, Yokochi F, Zrinzo L, Tison F: Short and long term outcome of bilateral pallidal stimulation in chorea-acanthocytosis. PLoS One 2013;8:e79241.

15 Walterfang M, Looi JC, Styner M, Walker RH, Danek A, Niethammer M, Evans A, Kotschet K, Rodrigues GR, Hughes A, Velakoulis D: Shape alterations in the striatum in chorea-acanthocytosis. Psychiatry Res 2011;192:29-36.

16 Tomemori Y, Ichiba M, Kusumoto A, Mizuno E, Sato D, Muroya S, Nakamura M, Kawaguchi H, Yoshida H, Ueno S, Nakao K, Nakamura K, Aiba A, Katsuki M, Sano A: A gene-targeted mouse model for choreaacanthocytosis. J Neurochem 2005;92:759-766.

17 Schmidt EM, Schmid E, Munzer P, Hermann A, Eyrich AK, Russo A, Walker B, Gu S, vom Hagen JM, Faggio C, Schaller M, Foller M, Schols L, Gawaz M, Borst O, Storch A, Stournaras C, Lang F: Chorein sensitivity of cytoskeletal organization and degranulation of platelets. FASEB J 2013;27:2799-2806.

18 Alesutan I, Seifert J, Pakladok T, Rheinlaender J, Lebedeva A, Towhid ST, Stournaras C, Voelkl J, Schaffer TE, Lang F: Chorein sensitivity of actin polymerization, cell shape and mechanical stiffness of vascular endothelial cells. Cell Physiol Biochem 2013;32:728-742.

19 Shiokawa N, Nakamura M, Sameshima M, Deguchi A, Hayashi T, Sasaki N, Sano A: Chorein, the protein responsible for chorea-acanthocytosis, interacts with beta-adducin and beta-actin. Biochem Biophys Res Commun 2013;441:96-101.

20 Godsel LM, Hobbs RP, Green KJ: Intermediate filament assembly: dynamics to disease. Trends Cell Biol 2008;18:28-37.

21 Kardassis D, Murphy C, Fotsis T, Moustakas A, Stournaras C: Control of transforming growth factor beta signal transduction by small GTPases. FEBS J 2009;276:2947-2965.

-22 Martinac B: The ion channels to cytoskeleton connection as potential mechanism of mechanosensitivity. Biochim Biophys Acta 2014;1838:682-691.

23 Tondeleir D, Vandamme D, Vandekerckhove J, Ampe C, Lambrechts A: Actin isoform expression patterns during mammalian development and in pathology: insights from mouse models. Cell Motil Cytoskeleton 2009;66:798-815.

-24 Clemen CS, Herrmann H, Strelkov SV, Schroder R: Desminopathies: pathology and mechanisms. Acta Neuropathol 2013;125:47-75.

25 Kontrogianni-Konstantopoulos A, Ackermann MA, Bowman AL, Yap SV, Bloch RJ: Muscle giants: molecular scaffolds in sarcomerogenesis. Physiol Rev 2009;89:1217-1267.

-26 Marshall JL, Kwok Y, McMorran BJ, Baum LG, Crosbie-Watson RH: The potential of sarcospan in adhesion complex replacement therapeutics for the treatment of muscular dystrophy. FEBS J 2013;280:4210-4229.

27 Stroud MJ, Banerjee I, Veevers J, Chen J: Linker of nucleoskeleton and cytoskeleton complex proteins in cardiac structure, function, and disease. Circ Res 2014;114:538-548.

28 Strnad P, Stumptner C, Zatloukal K, Denk H: Intermediate filament cytoskeleton of the liver in health and disease. Histochem Cell Biol 2008;129:735-749. 
29 Hall A: Rho family GTPases. Biochem Soc Trans 2012;40:1378-1382.

- 30 Infante E, Ridley AJ: Roles of Rho GTPases in leucocyte and leukaemia cell transendothelial migration. Philos Trans R Soc Lond B Biol Sci 2013;368:20130013.

31 Ouderkirk JL, Krendel M: Non-muscle myosins in tumor progression, cancer cell invasion, and metastasis. Cytoskeleton (Hoboken) 2014;71:447-463.

-32 Stournaras C, Gravanis A, Margioris AN, Lang F: The actin cytoskeleton in rapid steroid hormone actions. Cytoskeleton (Hoboken) 2014;71:285-293.

-33 Konstantinidis G, Moustakas A, Stournaras C: Regulation of myosin light chain function by BMP signaling controls actin cytoskeleton remodeling. Cell Physiol Biochem 2011;28:1031-1044.

34 Moustakas A, Stournaras C: Regulation of actin organisation by TGF-beta in H-ras-transformed fibroblasts. J Cell Sci 1999;112 (Pt 8):1169-1179.

-35 Vardouli L, Vasilaki E, Papadimitriou E, Kardassis D, Stournaras C: A novel mechanism of TGFbeta-induced actin reorganization mediated by Smad proteins and Rho GTPases. FEBS J 2008;275:4074-4087.

-36 Papakonstanti EA, Stournaras C: Actin cytoskeleton architecture and signaling in osmosensing. Methods Enzymol 2007;428:227-240.

-37 Schmidt EM, Gu S, Anagnostopoulou V, Alevizopoulos K, Foller M, Lang F, Stournaras C: Serum- and glucocorticoid-dependent kinase-1-induced cell migration is dependent on vinculin and regulated by the membrane androgen receptor. FEBS J 2012;279:1231-1242.

-38 Papakonstanti EA, Stournaras C: Association of PI-3 kinase with PAK1 leads to actin phosphorylation and cytoskeletal reorganization. Mol Biol Cell 2002;13:2946-2962.

-39 Papakonstanti EA, Stournaras C: Cell responses regulated by early reorganization of actin cytoskeleton. FEBS Lett 2008;582:2120-2127.

40 Stournaras C: The Functional Role of Actin Cytoskeleton Dynamics and Signaling in Early Cell Responses. ; in Advances in Molecular and Cell Biology. München, Elsevier, 2006, vol. 37, p.^pp. 181-200.

41 Stournaras C, Stiakaki E, Koukouritaki SB, Theodoropoulos PA, Kalmanti M, Fostinis Y, Gravanis A: Altered actin polymerization dynamics in various malignant cell types: evidence for differential sensitivity to cytochalasin B. Biochem Pharmacol 1996;52:1339-1346.

42 Chen Y, Chou WC, Ding YM, Wu YC: Caffeine inhibits migration in glioma cells through the ROCK-FAK pathway. Cell Physiol Biochem 2014;33:1888-1898.

43 Xiao Y, Qu C, Ge W, Wang B, Wu J, Xu L, Chen Y: Depletion of thymosin beta4 promotes the proliferation, migration, and activation of human hepatic stellate cells. Cell Physiol Biochem 2014;34:356-367.

44 Kallergi G, Agelaki S, Markomanolaki H, Georgoulias V, Stournaras C: Activation of FAK/PI3K/Rac1 signaling controls actin reorganization and inhibits cell motility in human cancer cells. Cell Physiol Biochem 2007;20:977-986.

45 Franklin-Tong VE, Gourlay CW: A role for actin in regulating apoptosis/programmed cell death: evidence spanning yeast, plants and animals. Biochem J 2008;413:389-404.

46 Papakonstanti EA, Stournaras C: Tumor necrosis factor-alpha promotes survival of opossum kidney cells via Cdc42-induced phospholipase C-gamma1 activation and actin filament redistribution. Mol Biol Cell 2004;15:1273-1286.

47 Papadimitriou E, Kardassis D, Moustakas A, Stournaras C: TGFbeta-induced early activation of the small GTPase RhoA is Smad2/3-independent and involves Src and the guanine nucleotide exchange factor Vav2. Cell Physiol Biochem 2011;28:229-238.

-48 Vardouli L, Moustakas A, Stournaras C: LIM-kinase 2 and cofilin phosphorylation mediate actin cytoskeleton reorganization induced by transforming growth factor-beta. J Biol Chem 2005;280:1144811457. 